\title{
The Roles of Food Industries as a Part of Food Tourism Development for Woman Empowerment in Bogor
}

\author{
Agustina Multi Purnomo, SP., M.Si \\ Curug Mekar No17 Yasmin Bogor, Sekolah Tinggi Pariwisata Bogor, Bogor City, West Java, Indonesia. \\ agustinamulti@yahoo.com.
}

\begin{abstract}
This study was conducted to determine the role of food tourism development on Disability Issues of Social Welfare (DISW) women's empowerment in Bogor. Preliminary studies indicate the role of food tourism development on DISW women's empowerment did by food industries, so this study focused on the role of food industries to empowering DISW women in the Bogor City and Regency. The study was conducted by using a triangulation approach and data collection techniques were a review of documents, surveys, interviews, and observations. The study was conducted in 23 micro-scale food industries and two small-scale food industries. The result showed the Bogor City and Regency has spearheaded the development of food tourism. The development of food tourism needs support of food industries development, vice versa. The development of food industries in Bogor especially the micro scale was absorbing the DISW women labor in Bogor. DISW women workers who do not have a college education, poor, family's main breadwinner, do not have skills and work experience accepted to work in micro-scale food industries. The same roles were not carrying out by small-scale food industries because they asked the qualification standards for workers. In terms of labor protection of women, micro-scale industries do not implement labor protection standards such as the certainty of continuity of employment, salary standard, fixed income given when maternity leave, illness or childbirth and holiday allowances. Based on the results of research, the development of food tourism was influencing development of the food industries and the development of the food industries especially micro-scale industries was absorbing the DISW women labor force. The roles of food tourism development for woman empowerment in Bogor were provide job opportunities to help woman to enhance their financial income, their work skill and opportunity to networking and training. The results showed the government and employers are expected to provide the protection of women workers.
\end{abstract}

Key words: women empowerment, food tourism, food industries

\section{INTRODUCTION}

Economic impact is not the only purpose of tourism development in West Java. The development of tourism in West Java conducted in the frame of local knowledge with one of its main goals is to improve the community's role in the development of sport, arts, culture and tourism (mission performance indicators RPJMD West Java 2013-2018). The development mission is or successful if it could be handled the number of Disability Issues of Social Welfare (DISW) minimum of 50 people per year and increase the Gender Empowerment Index (GDI) minimum 1 point per year. This shows the development of tourism in West Java was also devoted to the development efforts to empower women, especially DISW women.

In the City and Regency of Bogor, tourism is one the important part of economic development. It is the first mission listed in the development of Bogor states community economic development emphasizing on services that optimize the use of available resources. This mission means that development is directed to improvement of the people's economy and development of the service sector, including restaurants (tourism). It is also listed in the second mission of the development Bogor Regency stating that the development of natural resources and tourism-based businesses in the context of improving the competitiveness of the local economy. This means that the focus of tourism development Bogor Regency is based on natural resources tourism business which aims to strengthen the local economy.

Food tourism is a tourism concept that is likely to develop the potential of local food and local human resources within the framework of regional development (Hall and Jenkins, 1998; Jenkins, Hall and Troughton, 1998, in Hall, et al, 2003). The development of food and beverage tourism give the opportunity to develop the local food business, diversification of rural development, development of agricultural towns and villages, as well as the local hawker centers as a representation of the regional food market (Bessi'ere, 1998). According to Wood (2001, in Hall, et al, 2003) the arrival of tourist to tourist spots foods will also encourage community pride and reinforcement of local identity and culture.

Food tourism is a mode for tourist to try the local food (UNWTO, 2012). It defined as visitation to primary and secondary food producers, food festivals, Restaurants and specific locations for roomates food tasting and / or experiencing the attributes of specialist food production regions are the primary motivating factors for travel (Hall and Mitchell, 2001). Thereby, food tourism is intentioanlly driven to serve tourist that has a special interest to food as their reason to visit a tourism destination. In food tourism, tourists differentiate between tourists who consume food as a part of the travel experience and reviews those tourists whose activities, behaviours and, even, destination selection is influenced by their interest in food (Hall and Sharpless, in Hall et.al., 2003). Indeed, such is the need for food to be a primary factor in the Influencing travel behavior and decision making that as a form of special interest travel, food tourism may possibly be regarded as an example of 
culinary, gastronomic, gourmet or cuisine tourism that Reflects consumers for Whom interest in food and wine is a form of 'serious leisure' (Hall and Mitchell, 2001).

Food tourism can be graded according to the interest of the tourist. The grade is determined by the motive to travel, to enjoy specific food, drinks, market or specific restaurant to enjoy food, or go just as they feel hungry (Hall and Sharpless, in Hall et al, 2003). The development of Bogor City and Regency as a food tourism destination need support from the food industries in the form of restaurant or food and beverages manufactureras that shows the characteristics of Bogor. Food industries produce food and baverage as a key condition establishment either as gourmet food tourism or just a rural / urban tourism. In contrast, the growth of food torism and increased tourist interest in food and typical baverage will encourage the growth of foodproducing industry. Growth in the food-producing industry will push labor and ultimately contribute to the development of human resources in the region.

Additionally to support the development of food tourism, food industries also play a role in absorbing labor DISW (Sumarti et.al, 2011). Food-producing industry primarily in micro-scale the employment usually consist of women workers, less educated workers, carried out in housing scale and does not have a standard apllication of raw labor. Thus, everyone who is included in the target of the mission and objectives of the government of West Java, and the development mission of the city and Regency of Bogor may also be involved.

The industrial scale enterprises that produce traditional foods of Bogor are divided into micro, small, medium and largescale industries with respect to understanding the characteristics of the business according to Law No. 20 of 2008 on SMEs. Micro is a productive enterprise belonging to individuals and / or entities that meet the criteria of individual businesses Micro as stipulated in this Law. The criteri is having a maximum of 50 million rupiah asset with maximum turnover of 300 million rupiah. Small Business is economic enterprise productive that stand alone, conducted by an individual or business entity that is not a subsidiary or not a branch of the company owned, controlled, or be a part either directly or indirectly from medium or large businesses that meet the criteria of business small as defined in this Act. The criterion is having an asset of 50 million to 500 million rupiah, with turnover of 300 million to 2.5 billion rupiah. Medium Enterprises is a productive economic activities that stand alone, carried out by an individual or business entity that is not subsidiaries or branches of companies owned, controlled, or be a part either directly or indirectly by the Small Business or large enterprise with total net assets or annual sales revenue as stipulated in this Law. With criterion assets of 500 million to 10 billion rupiah, and the turnover criteri is more $>2.5$ billion to 50 billion rupiah.
The involvement of DISW in food industries is the first step in empowering the role of food industries for DISW women. This study uses the concept of empowerment of Ife (1995) where empowerment is seen as an integrated development effort involving the entire community including those who normally are not considered (women, poor, etc. that belong to the DISW), built and owned by the community and sustainability. The process of empowerment can not be separated from training and education, to build a professional in the community, building the values and ethics of the community itself and the long-term commitment (Ife, 1995). Within the framework of this study, women's empowerment DISW views of the role of food industries in providing training and education, developing the potential of women DISW in addition to fulfilling their basic rights as workers.

Based on the above studies, this study was conducted to determine:

a) How does the role of traditional Bogor foods business productions can support the food tourism in Bogor?

b) How does the role of food producing enterprises in the empowerment of women in Bogor?

Based on the research questions, the objectives of this research are:

a) Mapping the role of businesses producing traditional foods in favor of Bogor in Bogor travel food.

b) Mapping the role of food-producing enterprises in the empowerment of women in Bogor.

\section{METHOD}

The study was conducted in the City and Regency of Bogor. Bogor Regency was selected as location of study since there have been previous studies conducted at the same location and due to the comfort of researcher to grant network with stakeholders is needed because researcher have had a good relationship with them. Meanwhile, the location in the city of Bogor been selected for their good cooperation on the part of the City Government in supporting the implementation of the research. As the satelite area for the capital, the City and Regency of Bogor is also potential to be developed as a tourism object including food tourism.

This study was conducted in 23 micro-scale food industries and two small-scale food industries. The selection of micro-scale industry based on the previous research that the labor absorption DISW women in micro-scale industries more than in higher scales. Small-scale industries were observed as a comparison. Meanwhile, for the medium-scale food-producing industry was not investigated because the information needs for research has been represented by small-scale industries. All of the 23 food industries are a manufacturer of producing food and baverage known as a typical of Bogor foods. The specificity of the food is very 
important according to the definition of food torism in Hall and Mitchell (2001), which ephamsized on the specific location and also refers to specific food as the main attraction. The subject of research done purposively by first conducting in-depth interviews with cultural figures and the City of Bogor Regency regarding on typical Bogor food and baverage that have existed since time immemorial and is produced by food industries in the region of Bogor.

The study was conducted by using a triangulation approach; the approach was using several of methods of data collection or research techniques to seek a deep understanding of the phenomenon (Babbie, 2004). The techniques of data collection were a review of documents, surveys, interviews, and observations. The fifth of data collection techniques have to collect different types of complementary or explain the data and the data is collected through the data techniques collection. The choice of method of data collection is done in accordance with the purpose of research. This includes the type of data and data collection techniques thas has been done to achieve the research objectives.

\section{FINDINGS AND DISCUSSION}

\section{A. The Roles of Food Industries as a Part of Food Tourism Development in Bogor}

Based on the results of interviews with cultural observer, Department of Tourism and Culture and the Department Creative Economy of Bogor city and regency have showed there were at least 23 types of traditional food of Bogor managed by micro entrepreneurs and two kinds of traditional food of Bogor managed by small-scale entrepreneurs. From all the 23 industrial-scale microstructures are dodongkal, leupeut Cikereteg, ice kacang, beer kocok, cuka pala and nutmeg syrup, toge goreng, doclang, laksa Bogor, leupeut lapis, oil snap, kue ali, soto Bogor, permen pala, soto mie, Pak Emun sop , noodles golosor, guava crystals, dodol taro, taro chips, cassava chips and banana chips, traditional instant drinks, flour, sweet potato brownies and muffins, chips and dodol, sticky rice, dumplings. Two small-scale businesses are taro pie and crispy taro and Klapertart Huize and lapis Bogor.

During this past few times the food is not the main tourism destination in Bogor. This is just a new phase of rural / urban tourism and low interest in food tourism. Tourists come to visit local markets, food festivals, winery or restaurant because it is "something different" (Hall and Sharpless, in Hall et al, 2003) Referring to the tourist information in the city of Bogor, food tourism information only presents the types of typical food and baverage Bogor without explanation about location, history, or anything else about the food (http://kotabogor.go.id, accessed on February 29, 2016). Even in Bogor regency there is no information about culinary travel and tourism information it only provides images of some of the natural tourist sites (https://www.bogorkab.go.id, accessed on February 29, 2016). Culinary centers in Bogor become an additional destination after the tourists made a visit to nature-based tourism sites, conduct meetings, or other travel activities.

Observing the potential of traditional food and baverage of Bogor and the location of Bogor bordering the capital city, making Bogor as a food tourism development is feasible. Besides having a natural support for the development of farm-based food tours, and the City of Bogor district has thousands of food-producing businesses whose products have been known and identics with Bogor such as nutmeg and various processed nutmeg, pickled Bogor, roti Unyil, lapis Bogor, taro and various processed products. The food there is the category of traditional foods has long been known as the Bogor typical food, made from materials known as typical Bogor or food that was popularized as a traditional food of Bogor (Purnomo et al, 2015).

The efforts to develop industries producing food and baverage been conducted both by the City and Regency of Bogor. Department of Cooperatives, SMEs Trade and Industry (SMEs Trade and Industry) Bogor regency conduct regular programs include Creation Program Climate Conducive Small and Medium Enterprises and Entrepreneurship Development Program and SMEs Competitive Advantage. Both programs are broken down into 13 activities with a total budget of 1.961 billion. Both of these programs are regularly conducted every year in 40 districts in Bogor. A second output of this program includes; 1) the availability of the data of SMEs in Bogor, 2) trained SMEs to organize a business, 3) led to the birth of SMEs excel, 4) the implementation of the cooperation between SMEs and cooperatives, 5) lack of access to capital for SMEs, 6) their SME partnerships with the business world and 7) the implementation of legality and certification of products of SMEs (Ppid.bogorkab.go.id, accessed on 1 April 2015).

The effort to build food tourism has been conducted by the Bogor city such as by building Gang Aut region which has been known as a culinary center in Bogor as a hawker center and culinary tours of Bogor. Some of the Efforts are to clean the gang Aut carts of street vendors and socializing for environmental cleanliness (http://megapolitan.antaranews.com, accessed on February 29, 2016). City Government also provided display tradutional products including food and baverage from Bogor on the Mall. However, the display of these products has not been fully atracting in establishing a motive tourist coming to Bogor City specifically to enjoy the food and baverage.

Both the city and regency of Bogor and several academic institutions such as the Bogor Agricultural Institute has host a festival of food, drinks, fruit festival, agricultural products in a routine event or be part of another event. Those festivals 
that up to now have not become a specific destination chosen by the tourists to come to Bogor.

Enterprise producing food plays an important role in the development of food tourism in both the city and regency of Bogor. Foof and baverages as the main tourist attractions in torism food produced by food-producing businesses. Business development, especially food producers who produce traditional food and baverage of Bogor comes out with publications and policy areas to focus on development on food tourismt will encourage Bogor as a food tourism destination in Indonesia.

\section{B. The Roles of Food Industries in Woman Empowerment in Bogor}

\section{Acceptance of Labor Women DISW in Food Producing Industry}

The opportunity of the role of micro and small businesses producing traditional foods in Bogor absorb DISW very large. DISW female category is women workers who do not have a college education, poor, the family's main breadwinner, do not have skills and work experience accepted to work in micro-scale food industries. The whole micro-businesses do not require a minimum education requirement to work, not considering socioeconomic status of workers, and only $30 \%$ that require special skills. Here is the absorption of labor DISW at 23 micro-scale foodproducing industry in Bogor.

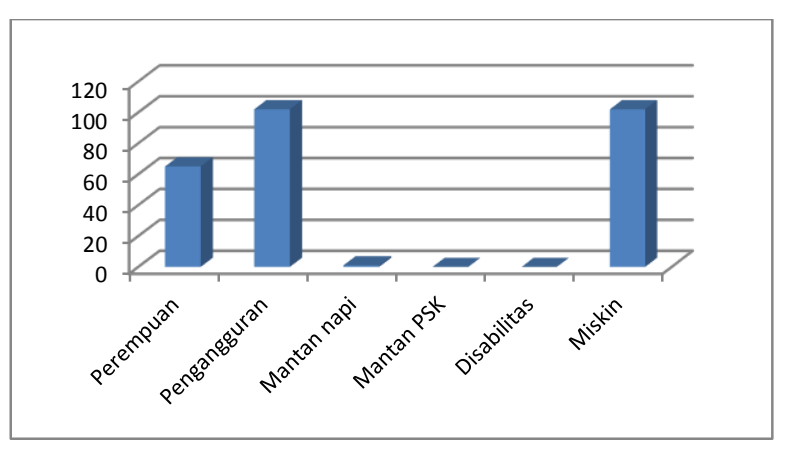

Figure 1. Total Employment DISW Category in the 23 Industrial Micro Scale Food Producers in Bogor

Resource: taken from primary data, 2015

In small-scale food-producing industry, women's labor absorption in total are 20 people, 33 people unemployed and 33 the poor. Category includes in the poor and unemployed people are alike. However, unlike the micro-scale industries, in small industry there is a minimum of high school education as a condition of hiring. Refers to the notion DISW, is not included in the DISW category.

Specifically on DISW women's labor absorption, priority of hiring women found in businesses that require accuracy, continuity, salaries are not too big and can be done at home or home workers. Women are considered not appropriate to work in businesses that are considered heavy tasks, such as selling using carts, selling at night, using heavy equipment, and businesses dominant with the male workers.

No former commercial sex workers (CSWs) who work in micro-enterprises and small businesses. Small industrial entrepreneurs explicitly not accept women ex-prostitutes. Industrial entrepreneurs of micro would only accept if the woman can work. Female of ex-prostitutes are more accepted as labor when compared to persons with disabilities.

\section{Labour Policy for Women Workers}

Based on the criteria of whether there is an employment contract, health benefits, birth allowance, education allowance, THR, the opportunity leave, maternity leave, sick leave salary fixed time, fixed salary when on maternity leave, and salaries remain when other licenses by using a simple vote of $0-4$ it can be seen that the small-scale enterprises to get the highest score. Klappertart Huize and Lapis Bogor and taro pie and crispy taro provide certainty on all points guarantees and benefits to women unless the benefits of education. Provision of monthly salary may encourage high point's guarantees and benefits for workers.

Monthly salary making workers still earns income during on leave and sick time. For an example on e leupeut Cikereteg and soto mie business that although the monthly salary is not for daily wages but still earn a license and sick time. Monthly salary does not necessarily ensure the number of bonus (THR), birth allowances and other benefits. This is indicated by the absence of four points on a business that provides a monthly salary as leupeut Cikereteg and soto mie as the indicators allowances above.

When added to the bottom with a minimum score of 0 and a maximum of 4 or from 29 enterprises, therefore a minimum score of 0 and a maximum of 116 , none of the indicators of security and welfare for workers who reach the maximum score or get a score of 4 on all businesses. The highest scores are on indicators get the chance leave (76), followed by bonus/ THR indicator (56) and medical benefits (52). Total score was lowest for the existence of a contract of employment (28) and a fixed salary given time off (30). This score does not indicate how many points certain scale or indicate how many levels at other points. This score can only give an idea to guarantee employment which is the most widely prescribed and given by the least effort. The lowest score was obtained by businesses that do not have the manpower like kue ali, oli jepret, leupeut petir, and beer kocok. The determining factor is the certainty of employment contracts. The employment contract caused workers can get certainty about their rights and responsibilities.

Total score indicates the ease to obtain employment in micro-enterprises producing food for DISW still need to be include with policies guarantee adequate employment. This 
responsibility can not be directly given only to the organizers of the business because of the scale of micro enterprises in some effort led to the organizers attempt to run a business to survive the daily targets so it is not possible to guarantee monthly income to the work force. In some categories of micro business enterprises, employers have been sufficient to give a monthly salary and adequate worker protection. Enterpreneurs is advised to implement policies welfare worker may apply.

\section{Role of Women Conducted by Food Producing Industry}

Analysis of the role of women's empowerment by the food-producing industry is done by using an indicator of empowerment of Ife (1995), in which the role of empowerment include the provision of education and training and developing the potential of women. Two indicators (employment and labor protection) was added referring to the results of research and the rights of labor. Indicator empowerment analyzed based on access, participation, control and benefits received by female workers. Analysis of access, participation, control and benefits of gender analysis refers to the pathway (GAP) which suggest the use in the preparation of gender responsive programs in Indonesia (KPPA, 2009). Analysis of access, participation, control and benefit shows women's access to resources, participation in resource management activities, participation in decision-making and the results obtained or enjoyed. Points are awarded by summing the rates of the 23 industry empowering role of micro then multiplied by $100 \%$. Small industries were not analyzed because the starting point of access to employment has obtained a value of 0 .

Table 1. The Role of Women in Micro Industries Food Producing Based on Analysis of access, participation, control, and benefits of the Empowerment Program

\begin{tabular}{|l|c|c|c|c|}
\hline $\begin{array}{c}\text { Empowerment } \\
\text { program }\end{array}$ & $\begin{array}{c}\text { Access } \\
\mathbf{( \% )}\end{array}$ & $\begin{array}{c}\text { Participation } \\
\mathbf{( \% )}\end{array}$ & $\begin{array}{c}\text { Control } \\
\mathbf{( \% )}\end{array}$ & $\begin{array}{c}\text { Benefits } \\
\mathbf{( \% )}\end{array}$ \\
\hline Work & 100 & 100 & 30 & 100 \\
\hline Labor protection & 50 & 50 & 20 & 50 \\
\hline $\begin{array}{l}\text { Education and } \\
\text { training }\end{array}$ & 50 & 40 & 10 & 40 \\
\hline $\begin{array}{l}\text { The development of } \\
\text { women's potential }\end{array}$ & 50 & 40 & 10 & 40 \\
\hline
\end{tabular}

Access value indicates the percentage of food-producing businesses that perform the role of empowerment. From all the empowering role of women business owners make, the percentage of female workers who are actively involved indicated by the value of participation. Control value indicates the percentage of female labor participation in the decision making activities of empowerment for him. The value of benefits shows the percentage of women workers who feel they have benefited from empowerment activities.

The value of participation in employment and labor protection equal to the value of access for all workers women participated actively. Value of different looks at the role of education and training and developing the potential of women. This is because not all women workers participated in the program. The value of benefits equal to the value of participation for only the female workers who take part in activities that benefit. Values have the lowest values compared to control access, participation and benefit. Control low value indicates a low chance of working women to participate in deciding the role of empowerment that will be made by the employer.

The results of empowerment measure from income, increased knowledge and work skills as well as increased confidence of DISW in society. From the third indicators, the presence of micro-scale food industries producing the greatest role in helping DISW women in obtaining income (98\%). Knowledge and skills are limited as knowledge and skills related to work performed (90\%). Increased confidence in the community also felt a DISW women $(85 \%)$ mainly due to an income for living expenses and help her husband to support for living.

\section{CONCLUSION AND SUGGESTION}

The results showed the Bogor City and Regency have spearheaded the development of tourism by organizing a festival of food specialties Bogor, publishing of Bogor typical food, made outlets and crafts Bogor in malls especially for food, managing food tourism venue and encourage Entrepreneurs Groups to help small-scale food producers. The development of the food tourism was encouraging development of food industries. The development of food industries in Bogor especially the micro scale was absorbing the DISW women labor in Bogor. DISW women workers who do not have a college education, poor, family's main breadwinner, do not have skills and work experience accepted to work in micro-scale food industries. The same roles were not carrying out by small-scale food industries or Limited Company business entity because they asked the qualification standards for workers.

The roles of micro-scale industries producing food on the empowerment of women from the side of entrepreneurs are constrained by the perspective that the work is more appropriate for men than women. In terms of labor protection of women, micro-scale industries do not implement labor protection standards such as the certainty of continuity of employment, salary standard, fixed income given when maternity leave, illness or childbirth and holiday allowances.

Based on the results of research, the development of food tourism was influencing development of the food industries and the development of the food industries especially micro-scale industries was absorbing the DISW women labor force. The roles of food tourism development for woman empowerment in Bogor were provide job 
opportunities to help woman to enhance their financial income, their work skill and opportunity to networking and training. The results showed the government and employers are expected to provide the protection of women workers.

\section{REFERENCES}

[1] C.M. Hall, R. Mitchell, and L. Sharpless, "Consuming places: the role of food, wine and tourism in regional development", in Food Tourism Around the World Development, management and markets, C. M. Hall, L. Sharples, R. Mitchell, N. Macionis and B. Cambourne, eds., Oxford: Elsevier Ltd., pp. 25-59

[2] C.M. Hall, and R. Mitchell, "Wine and Food Tourism. In Special Interest Tourism: Context and Cases". N. Douglas, N. Douglas, and Derrett, R., eds., Wiley. 2001, pp. 307-329.

[3] E. Babbie, "The Practice of Social Research". Wadsworth: Belmont, 2004, pp.

[4] J. Bessi 'ere, "Local development and heritage: traditional food and cuisine as tourist attractions in rural areas". Sociologia Ruralis, 38, 1998, pp. 21-34.

[5) J. Ife, "Community Development; Creating Community Alternativesvision, analysis and Practice". Longman Australia Pty Ltd: Melbourne, 1995, pp. 57-261.
[6] Kementrian Pemberdayaan Perempuan dan Perlindungan Anak (KPPA). 2009. “Pedoman Pelaksanaan PPRG Bagi Daerah”. KPPA.

[7] Ppid.bogorkab.go.id. Dinas Koperasi, UKM Perindustrian dan Perdagangan Kabupaten Bogor. Program Kerja. accessed on February 29, 2016.

[8] Purnomo, A. M., et.al. "Pengembangan Destinasi Wisata Oleh-Oleh Lokal Jawa Barat Berbasis Pemberdayaan Masyarakat”, Unpublished, Sekolah Tinggi Pariwisata Bogor: Bogor, 2015

[9] Rahmawati, L. 2016. "Warga Bogor Gotong Royong Percantik Kawasan Pecinan". Published http://megapolitan.antaranews.com, accessed on February 29, 2016.

[10] Sumarti, T., et.al. 2011. "Kajian Psiko sosial, Struktural dan Isue Gender Pada Perempuan Pengusaha Industri Rumahan Di Indonesia”. Unpublished. Bogor. PKGA LPPM IPB.

[11] UNWTO, "Global Report on Food Tourism; AM Report : Volume Four”, World Tourism Organization (UNWTO): Madrid, 2015, pp. 6-7.

[12] N. E. Wood, "The interdependence of farming and tourism in Vermont: quantifying the value of the farm landscape" Unpublished Masters thesis, Department of Community Development and Applied Economics, University of Vermont, in in Food Tourism Around the World Development, management and markets, C. M. Hall, L. Sharples, R. Mitchell, N. Macionis and B. Cambourne, eds., Oxford: Elsevier Ltd., pp. 6-7. 